\title{
Research Artick: : Traits association and variability study in blackgram [Vigna mungo (L.) Hepper]
}

\section{G. THAMODHARAN, S. GEETHA AND A. RAMALINGAM}

Article Chronicle: Received : 11.07.2017;

Accepted :

26.07.2017

KeY Words:

Variability, Blackgram, Rice fallow, Heritability, Association
Author for correspondence :

\section{G. THAMODHARAN}

Agricultural College and Research Institute, MADURAI (T.N.) INDIA Email: srigsiva852 @gmail.com

See end of the article for authors' affiliations
SUMMARY : The estimate of PCV was always higher than the GCV for all the observed traits. High GCV was observed for branches per plant (40.38), single plant yield (23.68) and clusters per plant (22.38). Likewise high PCV was recorded for branches per plant (83.83), single plant yield (50.80) and pods per plant (50.59). The high heritability estimate was observed for none of the traits while moderate heritability was recorded for 100 seed weight (32\%) alone. Likewise, the estimated GA as \% of mean was higher for branches per plant (40.07\%), clusters per plant (26.98\%) and single plant yield (22.74\%). Association analysis revealed that the single plant yield exhibited direct positive and significant simple phenotypic correlation and higher direct association with pods per plant, branches per plant and seeds per pod. Single plant yield was increased with relative increases in these traits hence, emphasis had to be given on these traits in selection of genotypes for higher yield in blackgram.

How to cite this article : Thamodharan, G., Geetha, S. and Ramalingam, A. (2017). Traits association and variability study in blackgram [Vigna mungo (L.) Hepper]. Agric. Update, 12 (TECHSEAR-4): 1019-1023; DOI: 10.15740/HAS/AU/12.TECHSEAR (4)2017/1019-1023. 